Soloviev, V., Bakhmutov, V., Yakymchuk, N.,

Korchagin, I. (2021). Deep structure and new experimental data of the Bransfield Strait

volcanoes (West Antarctica).

Ukrainian Antarctic Journal, 1, 3-15.

https://doi.org/10.33275/1727-7485.1.2021.661
Геолого-геофізичні

дослідження

Geological and Geophysical

Research

V. Soloviev ${ }^{1, ~ *, ~ V . ~ B a k h m u t o v ~}{ }^{1,3}$, N. Yakymchuk ${ }^{2}$, I. Korchagin ${ }^{1}$

${ }^{1}$ S.I. Subbotin Institute of Geophysics, National Academy of Sciences of Ukraine, Kyiv, 03680, Ukraine

${ }^{2}$ LLC Institute of Applied Problems of Ecology, Geophysics and Geochemistry, Kyiv, 01133, Ukraine

${ }^{3}$ State Institution National Antarctic Scientific Center, Ministry of Education and Science of Ukraine, Kyiv, 01601, Ukraine

*Corresponding author: solvalera@ukr.net

\title{
Deep structure and new experimental data of the Bransfield Strait volcanoes (West Antarctica)
}

\begin{abstract}
The aim of the study is to determine the existence of a complex magma-gas-fluid system of the West Antarctica northern volcanic branch in the Bransfield Strait. It consists of several different-level deep magma chambers with magmas raised directly from the mantle or the accumulation zone located at a depth of about $25-30 \mathrm{~km}$. Research methods are based on the known idea that the Earth can be considered a spherical capacitor formed by various layers from its core to the surface with different parameters - thickness, permittivity, density, contact potential difference. Our experimental data show that there is a molten zone at 195-225 km where considerable part of volcanic roots is located. Certain structural patterns for land and submarine volcanic structures are revealed, and the first data on the deep migration channels of fluids in the Bransfield Strait are obtained. Volcanic channels are filled with different basic, ultramafic rocks, and sedimentary rocks too. The deep roots of volcanic structures' presence can be associated with the pulsed functioning of a gas-fluid channel with low viscosity. The gas-saturated melts form some zones of intermediate crystallization in the crust due to this channel. These studies showed that multiphase pulsed volcanic activity mainly through the vertical migration channels of deep fluids from the melting zone played a significant role in forming the tectonic diversity and the evolution of the Antarctic continental margin region structures. The results of modified methods of processing and decoding satellite images and photographs allow supplementing the understanding of the West Antarctica structures' formation. These results of the Bransfield Strait magmatic systems studying indicate the need for further research to understand the mechanism of formation and evolution of structures and deep geospheres in different regions of the Earth.
\end{abstract}

Keywords: deep structure, fluids, submarine volcanoes, mobile technology, remote sensing, data processing

\section{Introduction}

The variety of volcanism structural forms (including modern) reflects the different scales of near-surface and deep geological processes of the Earth's geospheres' evolution. Therefore, research of separate volcanoes' structure and the volcanic structures' magmatic system is essential for understanding the role of volcanism in the Earth's lithosphere geological structures' formation, as well as for a wide range of scientific and applied problems.
Some schematic sections and new experimental data on the deep structure of some volcanoes of West Antarctica obtained in Ukrainian Antarctic expeditions (UAE) (Bakhmutov et al., 2017; Soloviev et al., 2016; Yakymchuk et al., 2019) are shown.

\section{Data and methods}

Research methods are based on the ideas of N. Tesla, who considered the Earth as a spherical capacitor formed by various layers from its core to the surface 
with different parameters - thickness, permittivity, density, contact potential difference. Each object in nature has its own electric charge and creates a corresponding electric field strength and corresponding standing half-waves with other Universe objects (Yakymchuk, 2014). The developed technologies are focused on studying the structure of the surface layer of the atmosphere, which is formed by ions of various signs, polarization zones at the interfaces of the geological heterogeneities of section, and the Earth's natural electromagnetic background.

The vertical electro-resonance sounding method (VERS) is based on the geoelectric heterogeneities polarization effect of section in the Earth's natural quasi-stationary electric field. Inhomogeneity of the geological section characterized by geoelectric parameters of the environment anomaly values is polarized in the Earth field, forming a system of electric dipoles. Electric dipoles emit electromagnetic waves with a wavelength of $\mathrm{L}=2 \mathrm{H}$, where $\mathrm{H}$ is the depth to the surface of the polarized object with changing of the Earth's natural electric field E (z) magnitude. This allows assessing the depth of geoelectric objects anomaly. The further implementation of these ideas was the development of a "real" geophysical exploration paradigm (Levashov et al., 2012), the essence of which is isolation and localization of the specific substance's signal (frequency).

Resonant frequencies of mineral and rock bases are used in the modified methods of frequency-resonance processing of satellite images (Landsat-7, -8, Google Earth). The collection of oil samples in the base includes 117 samples, gas condensate - 15 samples. Sedimentary rocks include groups: 1 - psephytes; 2 - psammites; 3 - siltstones, argillites, clays; 4 kaolinite argillites; 5 - kaolinite clays; 6 - sedimentary-volcanic rock; 7 - limestones; 8 - dolomite; 9 marls; 10 - siliceous rocks; 11 - salt. Groups of igneous and metamorphic rocks are as follows: 1 granites and rhyolites; 2 - granodiorites and dacites; 3 - syenites and trachytes; 4 - diorites and andesites; 5 - lamprophyres; 6 - gabbro and basalts; 7 ultramafic rocks; 8 - syenites and phonolites; 9 gabbroids and basaltoids; 10 - ultramafic and mafic breeds; 11 - kimberlites and lamproites; 12 - car- bonate; 13 - granulites; 14 - gneiss; 15 - crystalline shales. Photographs of sets of samples of sedimentary, metamorphic, and igneous rocks used are borrowed from the electronic document on the website http://rockref.vsegei.ru/petro/. Features of the used methods and technique of measurements are described in more detail in (Yakymchuk, 2014; Levashov et al., 2012; Yakymchuk et al., 2019).

The direct frequency resonance methods provide a real opportunity to fill the investigated section with appropriate complexes of sedimentary, metamorphic, and igneous rocks immediately in the process of measurements (signal registration) by developed hardware-measuring devices without additional stages of modeling and geological interpretation of the results of geophysical measurements.

The revealed direct relationship between the position of the atmosphere's various layers height and the Earth's lithological boundaries with high contact potentials, as well as reference frequencies for different types of rocks and minerals, allow using frequency resonance methods to study the deep structure of our planet and solve problems of searching for many types of minerals. The results of modified methods use for processing, and decoding satellite images and photographs allow supplementing the understanding of the underlying processes of the West Antarctica structures' formation (Yakymchuk et al., 2019).

\subsection{A brief overview of West Antarctica volcanoes}

About 150 volcanoes have been discovered in the Antarctic Peninsula region (Vries et al., 2017). Many of them are inactive volcanic structures that are buried under thick ice (up to several kilometers) and grouped in volcanic provinces along the coast of the continent (Fig. 1).

Elevated surface temperature gradients in the western part of Antarctica (Steig et al., 2009) can be largely associated with the presence of local volcanic structures, systems of deep and near-surface magma chambers, and channels that form the thermal field of this region (Fig. 1).

The spatial connection of this volcanic formation system with the coastal structures indicates that a sig- 


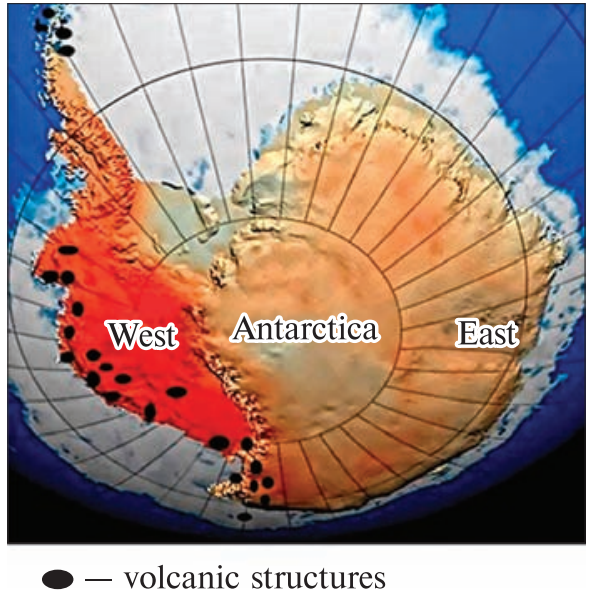

(a)

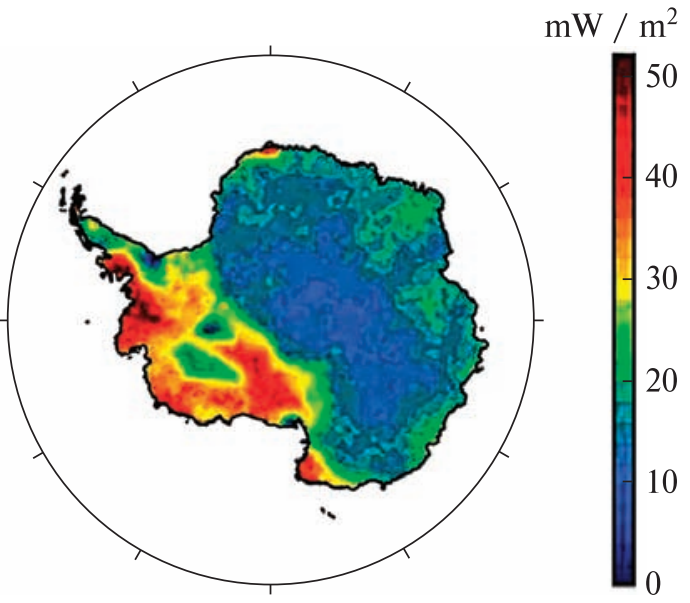

(b)

Figure 1. Schematic distribution map of ground temperature gradients in Antarctica (a) according to the results of measurements for 50 years (1956-2006), by (Steig et al., 2009) and the mantle heat flux (b), by (Lösing et al., 2020). The position of separate volcanoes in West Antarctica is shown. More intense color corresponds to increased gradients and heat flux (a)

nificant amount of the volcanoes is associated with extended segments of the West Antarctic rift zone (Vries et al., 2017).

Below is a brief overview of the available geological and tectonic ideas about the nature of the formation of the Bransfield Strait and its volcanic structures (Fig. 2).

\subsection{On geophysical models and the deep structure of the Bransfield Strait}

The Bransfield Strait is one of the key objects in the study of riftogenesis and structures evolution of the Pacific continental margins (active and passive types). The results of geological and geophysical studies of the lithosphere structures of the Drake Passage and the continental margin of the Antarctic Peninsula contributed to the development of new ideas about deep structure and multifactorial tectonic transformations of West Antarctica (Bakhmutov et al., 2017; Berrocoso et al., 2016; Catalan et al., 2013; Dubinin et al., 2013; Kozlenko \& Kozlenko, 2011, 2019; Geyer et al., 2019; Janik et al., 2014; Lodolo \& Perez, 2015; Pedrera et al., 2012; Prudencio et al., 2015; Schreider et al., 2015; Teterin, 2011).
This $400 \times 80 \mathrm{~km}$ Basin is located between the South Shetland Islands in the north and the Antarctic Peninsula in the south (Fig. 2). The Strait has a total area of more than $65000 \mathrm{~km}^{2}$ and has an asymmetric cross-section (from north to south). Within its limits, three (Western, Central, and Eastern) basins are distinguished (Fig. 2).

The Western Basin borders with the Central Basin in the region of Deception Island (Fig. 1) and has a length of about $130 \mathrm{~km}$ (with a width of $70 \mathrm{~km}$ ). The average depths here range from $1500 \mathrm{~m}$ to $1900 \mathrm{~m}$. Large submarine volcanoes with modern activity within have not been identified. There are known only small seamounts and volcanic structures connected with local tectonic submeridional faults.

The Central Basin of Bransfield Strait is elongated at about $230 \mathrm{~km}$ (with a width of $60 \mathrm{~km}$ and a maximum depth of $2.0 \mathrm{~km}$ ). Its characteristic feature is the presence of large volcanic structures (Figs. 1, 2), isometric (Axe and Orka), or elongated along the axis of the trough structures (Three Sisters and Hook Ridge). All volcanic structures are practically without sediments known in adjacent parts of the basin (Schreider et al., 2015).

The Eastern Basin borders the Central Basin in the area of Bridgeman Island (Fig. 1), where seismic acti- 


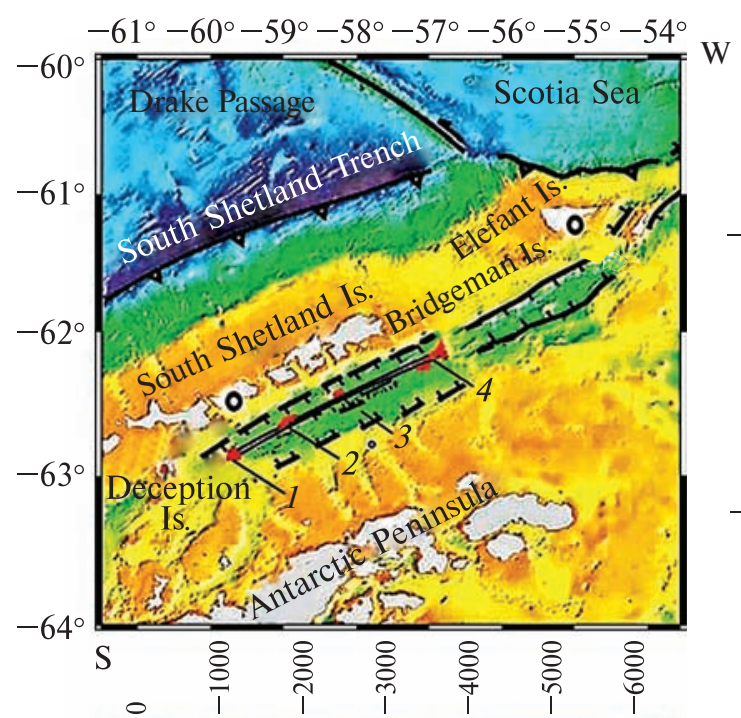

$H, \mathrm{~m}$ (a)
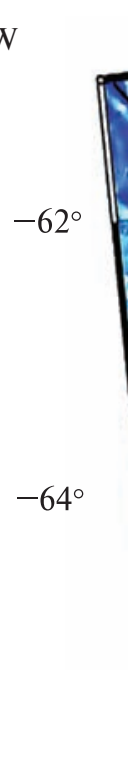

$-65^{\circ}$

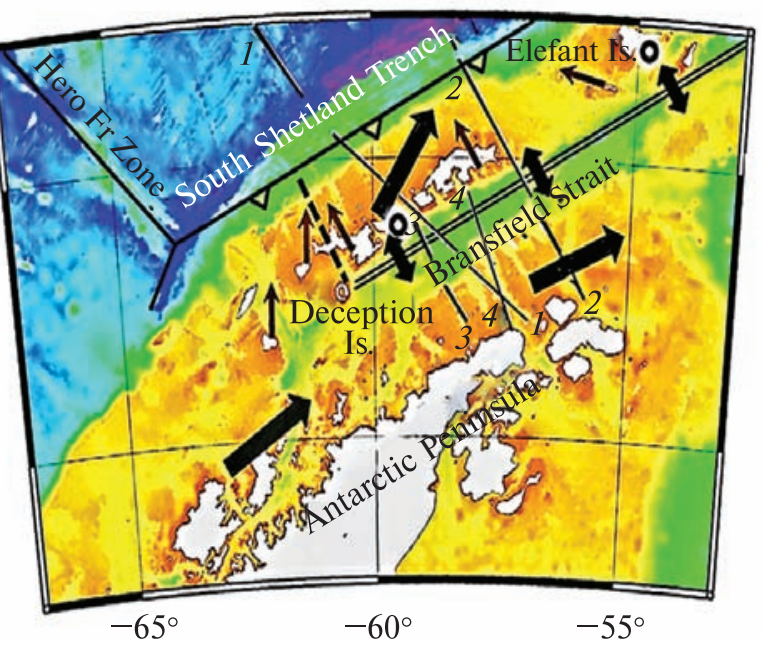

(b)

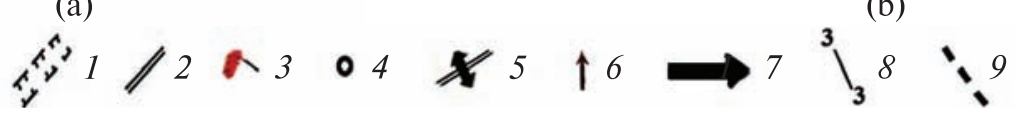

Figure 2. Bransfield Strait near the Antarctic Peninsula and volcanic structures' position (a), by (Lodolo \& Perez, 2015); vector directions in the Bransfield Strait by (Berrocoso et al., 2016) and model profiles position (b). Legend: 1 - the Bransfield Strait trough; 2 - axis; 3 - volcanic structures 1 - "Exe"; 2 - "Three Sisters"; 3 - "Orka"; 4 - Hook Ridge; 4 - VERS-point; 5 vectors of horizontal movement at the axis zone; 6 - vectors of regional movements relative to the Antarctic Plate; 7 - vectors of absolute horizontal movement; 8- profiles position: 1-1-by (Kozlenko \& Kozlenko, 2011); 2-2 - by (Teterin, 2011); 3-3 - by (Catalan et al., 2013); 4-4 - by (Kozlenko \& Kozlenko, 2019); 9 - fracture zone

vity is most intense. The basin extends at about $150 \mathrm{~km}$ (with a width of about $50 \mathrm{~km}$ and a maximum depth of $2.7-2.9 \mathrm{~km}$ ). Its features are the increased depth, the absence of large volcanic structures, and the relative elevation of the acoustic foundation (by $0.5-1.0 \mathrm{~km}$ ) and Moho.

The Central Basin area exceeds $30000 \mathrm{~km}^{2}$. According to morphology, the trough of the central part of the Bransfield Strait can be characterized as an active rift trough (with coaxial volcanic structures) that separates two continental blocks. The neovolcanic zone is an important structural element of the Bransfield Strait.

In the history of the formation of Bransfield Strait, several stages of the continental crust extension and cracking with the formation of a graben system (north of the Antarctic Peninsula) are distinguished. Also, there are noted active volcanic activity and formation of volcanic structures, as well as the deposition of stratified sediments with a thickness of about $0.2-0.8$ $\mathrm{km}$ (Schreider et al., 2015).

The Bransfield Strait rift, most expressed in the central part of this Strait, may be part of the rift system traced from the South Sandwich Island Arc to Deception Island (Udintsev et al., 2010). Modern tectonic activity in the Strait is confirmed by increased heat flow and many volcanic activity centers. Highprecision GPS measurements determine the spread velocity of about $10 \mathrm{~mm} /$ year orthogonal to the Strait strike (Fig. 2b). That is why the Central Basin of the Bransfield Strait may be attributed to the rift zone region with the deep structure of the mid-ocean ridge spreading formation (Dubinin et al., 2013).

Various authors attribute the Bransfield Strait either to marginal basins with oceanic crust or to backarc basins with reduced and stretched continental crust. The age of the Strait ranges from $37-26$ to $4-3$ million years, and the views on the nature of exten- 
$\Delta \mathrm{g}, \mathrm{mGal}$

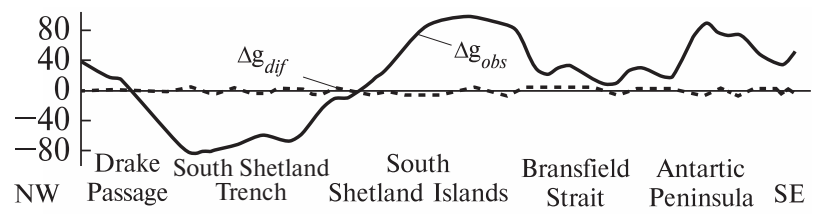

NW Passage Trench Shetland Islands Strait Peninsula SE

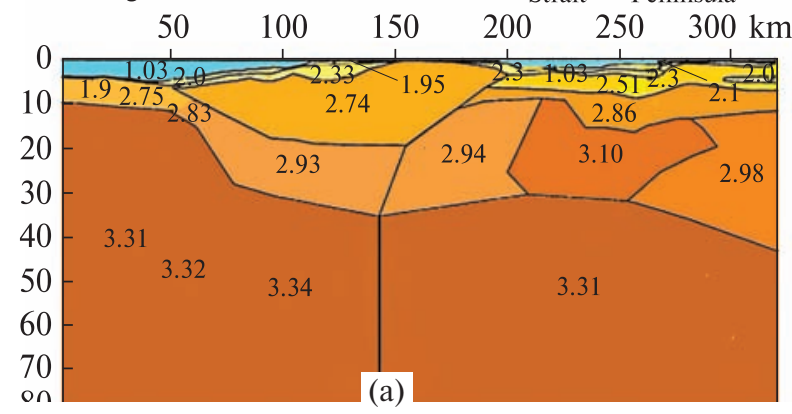

$\Delta \mathrm{g}, \mathrm{mGal}$

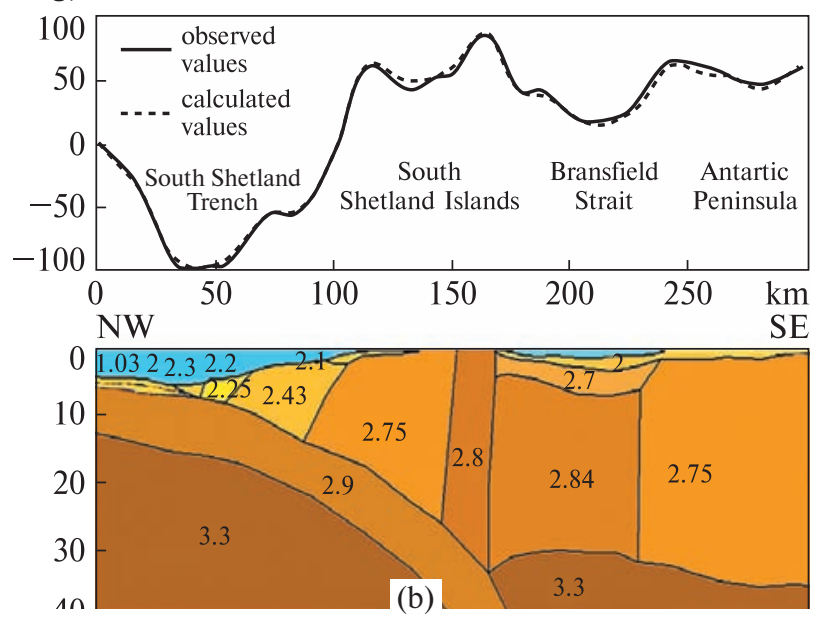

Figure 3. The results of complex modeling of marine gravity data along with profile $1-1$ (a), by (Kozlenko \& Kozlenko, 2011), and profile 2-2 (b) across the Bransfield Strait by (Teterin, 2011). Numbers are density values in $\mathrm{g} / \mathrm{cm}^{3}$. The profiles position in Fig. 2b

sion processes also vary (Bakhmutov et al., 2017; Berrocoso et al., 2016; Catalan et al., 2013; Dubinin et al., 2013; Kozlenko \& Kozlenko, 2011; 2019; Lodolo \& Perez, 2015; Pedrera et al., 2012; Schreider et al., 2015; Teterin, 2011).

The results of complex geological and geophysical modeling along profiles $1-4$ (Fig. 2b) comparison shows the ambiguity of the interpretation results for the deep structure and geodynamic evolution of this region.

According to the authors of seismic works, profiles across the Drake Passage and Bransfield Strait indicate subduction of the Phoenix oceanic plate fragments in the South Shetland Trench. Opening of the Bransfield Strait and the formation of back-arc rift basin with manifestations of modern volcanic activity in its central part (Janik et al., 2014) as was a consequence of its deceleration result, which occurred (according to the interpretation of linear dated magnetic anomalies) in the Drake Passage about 4 million years ago. Similar conclusions, based on complex modeling with profile 1-1 (DSS-17), were also reached (Bakhmutov et al., 2017). The gravity-magnetic model along profile 3-3 (Fig. 2b) in the central part of the Bransfield Basin showed (Catalan et al., 2013) that the Bransfield Strait was an active back-arc basin formed in the process of separation of the South Shetland Islands block from the Antarctic Peninsula. The important role of subduction processes and the promotion of tensile deformations from the South Scotia Ridge in the Bransfield Strait rift zone formation was also indicated (Lodolo \& Perez, 2015).

The good convergence of the model and observed fields in both cases may indicate correctly selected model parameters of these structures (Fig. 4.). However, there are completely different geological and tectonic interpretations of the presented models (Kozlenko \& Kozlenko, 2011; Teterin, 2011).

Authors of the seismic-density model (Fig. 3a) along profile 1-1 (DSS-17) considered that it was impossible to create a density section that was adequate to the seismic model (Kozlenko \& Kozlenko, 2011). Such a result, possibly, may indicate no reality of subduction processes within the continental margin near the Antarctic Peninsula.

Completely other geological and tectonic interpretations of the geodynamic evolution of the Drake Passage and Bransfield Strait based on the constructed seismic density model (Fig. 3b) were given in (Teterin, 2011): "Stopping spreading process at the Aluk Ridge (3.3 million years ago) led to the redistribution 
of the complex configuration of the axes of tension and compression associated with the mutual movements of the plates of the Antarctic, Scotia, Shetland, and Phoenix. It was the trigger for the beginning of the advancement of tensile deformations from the South Scotia Ridge and the formation of the Bransfield Strait rift".

Thus, complex geophysical models have been built for profiles across the Bransfield Strait that radically differed in the deep structure parameters and geological and tectonic conclusions.

The regional influence of anomalously heated substance (to a depth of 150-200 km) on geodynamic processes in the Drake Passage, South Shetland Islands, and the Bransfield Strait area significantly changes the distribution of the lithosphere and upper mantle density inhomogeneity. But these anomalies remained out of modeling. It was previously shown that the total, differentiated by area, effect of the activated mantle anomalous temperatures on the density distribution relative to "normal" mantle could exceed $-150 \mathrm{mGal}$ in this area (Bakhmutov et al., 2017).

A common element for all the proposed models is the presence of a crust-mantle mixture (heated mantle material) block in the deep section (Fig. 3) of the Central Basin of the Bransfield Strait. It is likely that the formation of a young rift system in the Central Basin of the Bransfield Strait, localized under the axis of the trough, is associated with a split in the axial part of the Strait, the rise of heated material, and the subsequent formation of a neovolcanic zone (Romashov, 2003).

Using additional and independent data, including results from isotope-geochemical and petrological studies, tomography, experimental data on the physical properties of rocks at high pressures and temperatures, as well as on the frequency-resonance and other characteristics of rocks and individual lithosphere blocks, complements the possibilities of a comprehensive analysis of tectonics and geodynamics of this vast region.

Volcanic rocks of the distinct zone from Deception Island to Bridgeman Island (Fig. 2) have to vary along with the Strait axis geochemical and isotopic features. Selected from the submarine volcanoes rocks at the northeastern part of the Bransfield Strait were assigned to three different groups, one of which was closed to basalts of the mid-ocean ridges, the second to basalts of the South Shetland volcanic arc, and the third - to a specific mantle source of Pacific Ocean mid-ridges (Udintsev et al., 2010). The intermediate geochemical composition of the studied basalts can be explained by the significant influence of the thermal effects of mantle rocks, which were raised to the upper horizons of the earth's crust of the coast of the Antarctic Peninsula from common sources of the formation of the asthenosphere melts. It is assumed that their melting occurred at a depth of 10-12 km (Geyer et al., 2019; Shnyukov et al., 2013).

Detailed studies of a geochemical composition of a number of the Bransfield Strait volcanoes showed that not only processes of slow subduction in the South Shetland Trench have great importance, but also the South Scotia Ridge fault zone formation (in SW direction) during the last 3 million years. That is why the authors (Fretzdorff et al., 2004) argue that the Bransfield Strait is not a back-arc but a marginal basin with active tensile processes.

\subsection{On the volcanic structures of the Bransfield Strait}

There are a number of volcanic structures of the Bransfield Strait, which form the northern volcanic branch in West Antarctica near the Antarctic Peninsula (Figs. 1, 2).

The largest of them include the active overland volcano Deception Island, as well as the submarine volcanoes of Orca, Three Sisters, and others (Fig. 2).

The Strait structures are segmented into separate blocks, which differ in wave characteristics and correlate with the volcanic centers of the axial zone. It should be noted that three identified Basins of the Strait exhibit differences in the manifestation of volcanism. Four volcanic structures are distinguished in the Western and Eastern Basins. The most active volcanism, accompanied by the formation of sufficiently large submarine volcanoes (more than 10), is confined to the Central Basin (Fig. 2).

The local volcanism of the Central Basin of the Strait is replaced eastward by volcanism with a sig- 


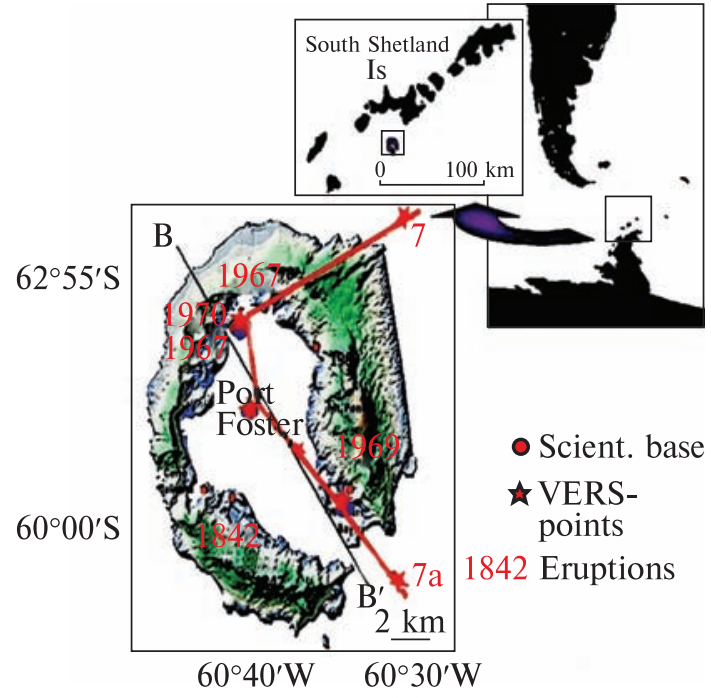

(a)

Figure 4. Scheme (a) of the Deception volcano location, by (Prudencio et al., 2015), with the profile 7-7a, VERS points (Levashov et al., 2008) and profile B-B' position; (b) - interpretation results along with the B-B'profile; (c) - VERS - section along with profile 7-7a. 1 - water; 2 - the first sedimen-

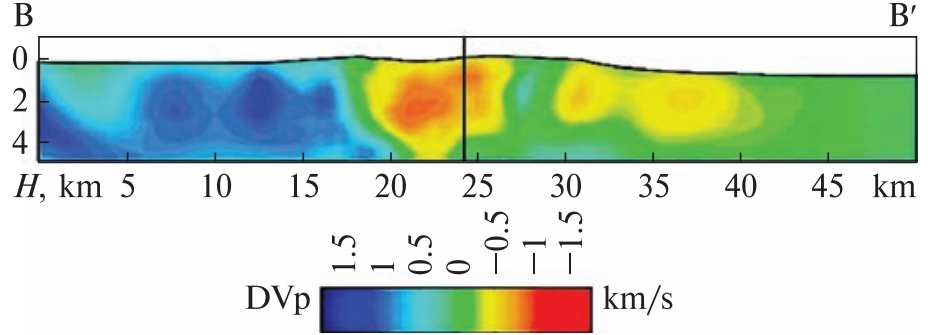

(b)
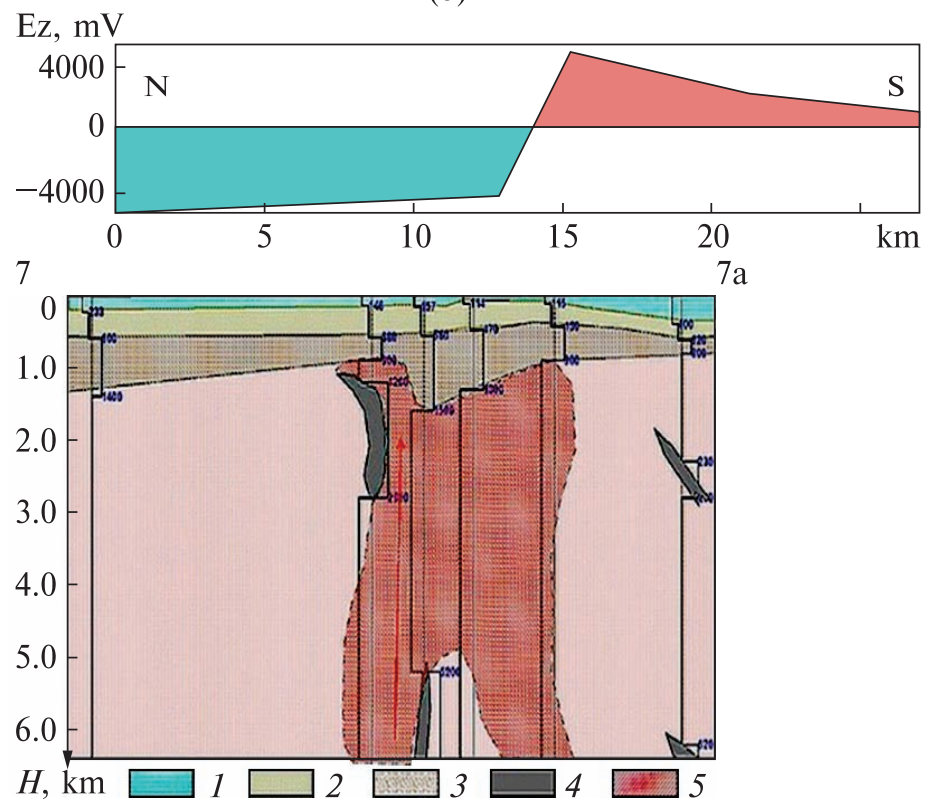

(c)

tary layer of low geoelectric resistance (silts, clay, sand deposits); 3 - the second sedimentary layer of increased geoelectric resistance (zones of clastic material, moraine deposits, crushing zones of the upper part of basement rocks); 4 - zones of increased polarization and geoelectric resistance at the basement (dike zone); 5- heating zone at the basement (crushed zone)

nificant amount of crack-like structures. This region is characterized by modern tectonic processes, accompanied by active volcanic activity from the Holocene to the present day on the islands of Deception, Penguin, Bridgeman. Active modern seismic events are associated with tectonic movements and local gas eruptions through the vents of submarine volcanic.

Deception Volcano - a multiphase caldera-type stratovolcano - is located on the island of the same name in the Bransfield Strait (Fig. 2). The volcano caldera (Port Foster Bay) was formed more than 10.000 years ago, wherein the ejection of melted magma was about $30 \mathrm{~km}^{3}$. This volcano is one of the few Antarctic overland active volcanoes that periodi- cally displays its volcanic activity and carries a potential threat to the environment, personnel of the island's research stations, as well as to flight safety in the region (Geyer et al., 2019; Pedrera et al., 2012; Prudencio et al., 2015).

\section{Results and discussion}

The VERS method interpretation results along profile 7-7a (Fig. 4) through the caldera of the Deception volcano showed that the total thickness of the sedimentary rocks at volcano caldera (and beyond) varies from $0.5-0.7 \mathrm{~km}$ to $1.3-1.7 \mathrm{~km}$. The zone of reduced resistance is mapped (to a width of $3-5 \mathrm{~km}$ ) in the central part that was explained by the presence 


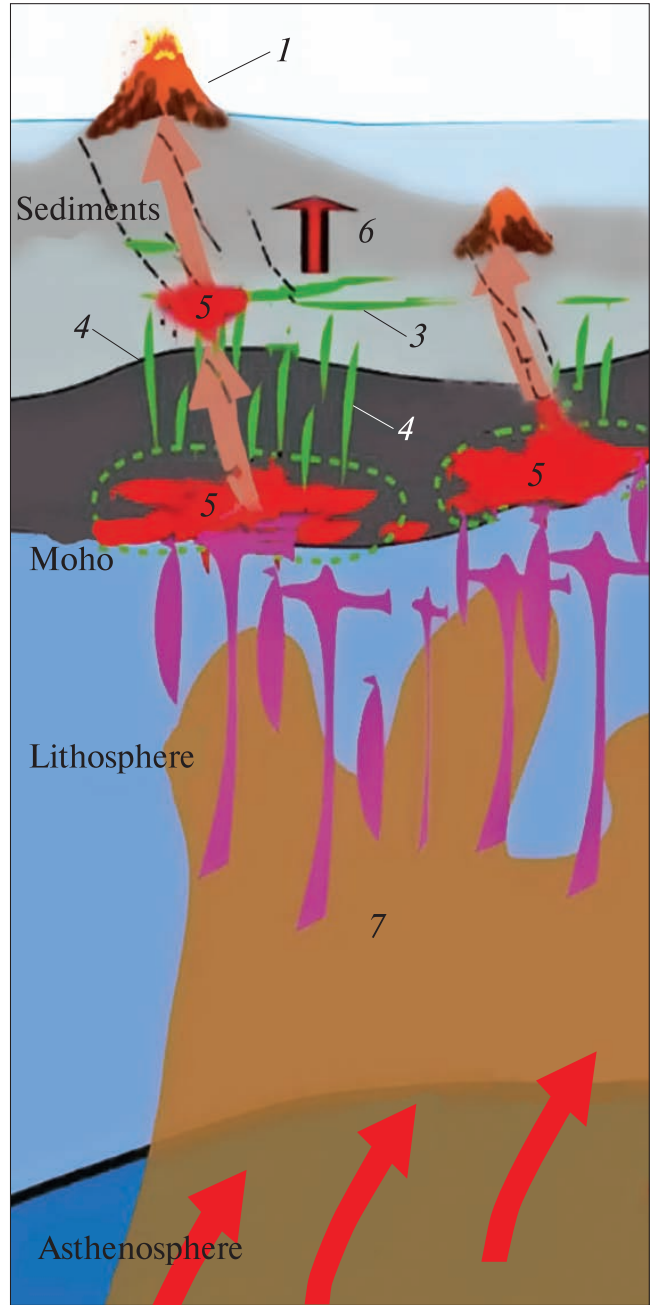

Figure 5. Schematic diagram of the volcanic structures formation and multilevel magmatic melts in the lithosphere (Xia et al., 2018, modified). 1 - volcanoes; 2 - folds of compression; 3 - sills; 4 - dykes; 5 - chambers with magmatic melts; 6 intrusions; 7 - crust-mantle rocks

of partially molten substance (at a depth of $1.5-6.5 \mathrm{~km}$ ). Local zones of increased resistance and polarization are interpreted as dike zones located in the central part of the profile and the caldera outside.

The VERS data and the results of later seismic tomographic studies have common structural characteristics of the upper part of the Deception volcanoes crust (Pedrera et al., 2012; Prudencio et al., 2015; Zandomeneghi et al., 2009). Magma chamber with partially melted matter under the caldera existence can explain the features of the modern hydrothermal regime, formation of anomalies, and fracture systems with active fluid migration in near-surface waters. Deception Island hydrothermal activity in the area with many of land craters, fumaroles, and submarine volcanoes is a result of different local and regional processes of the tectonic and geodynamic evolution of this region.

The size of the magma chamber, from the intense anomaly of reduced velocity determined, is close to the size of the zone of reduced resistance according to the VERS data (Fig. 4). The mosaic distribution of velocity anomalies largely coincides with the heterogeneity of the caldera section by geoelectric data (significant fluctuations in the thickness of precipitation, the inclusion of dikes, and zones of possible heating). We assume that this section characterizes a near-surface intermediate chamber, in which heated gas-volcanic material comes from deeper sources.

The possible depth of the Deception volcano's deep magmatic melts is $25-30 \mathrm{~km}$ (Shnyukov et al., 2013). The actual position of the lower boundary of the gassaturated melts channel for most volcanic structures remains unknown due to limited information on their deep structure. Therefore, experimental data are of interest, indicating that it is possible (in principle) to determine the magma melts location for the volcanoes of various types (Yakymchuk \& Korchagin, 2019).

Regional changes in the Earth's crust thickness of the Deception volcano identified by seismic data and potential fields' data interpretation were also confirmed by VERS data (Levashov et al., 2008). These data show the real reduction of the Earth's crust in the areas of the submarine volcanoes of the Bransfield Strait location. It should be noted that the thinned crust is characteristic of the entire area of the West Antarctica volcanic structures development.

The spatial heterogeneity of the Moho boundary distribution in the Bransfield Strait is associated with the complex deep architecture of the Strait lithosphere that formed under the influence of regional processes of the upper mantle heated rocks elevation. The rise of these melts controls volcanism development along the rift axis. The reduction in the thickness of the Earth's crust in the areas of the submarine volcanoes location at the Bransfield Strait confirms 
the presence in the lithosphere of favorable conditions for zones of intermediate crystallization formation. Modeling local magnetic anomalies over volcanic structures indicates the crustal distribution of their sources at depths of $8-12 \mathrm{~km}$.

The results of petrological and geochemical modeling (Geyer et al., 2019) showed that part of magmas of the Deception volcano post-caldera eruptions located mainly at depths from 2 to $10 \mathrm{~km}$. They formed a complex network of separate, potentially interconnected, small reservoirs of variable size, volume, and composition.

Part of magmas that supply the Deception volcanoes system could rise directly from the mantle or the chamber located near the Moho boundary $(25-30 \mathrm{~km})$. The magma chamber system under the island (Geyer et al., 2019) may consist of magma residues born at the caldera- and post-caldera formation stage, as well as part of magma that has invaded in recent decades (1992, 1999, and 2014-2015). The small magma reservoirs may be associated with faults that control the caldera formation. The volcanic structure of the Deception Island with magmatic melts position is in good agreement with the generalized layout of multilevel magmatic formations in the continental margin lithosphere (Fig. 5). The varied position of the magma chambers in the crustal section can be associated with the deep chambers regime features and magma pulsed flow energy into the volcanic structure.

The geological and geophysical characteristics testify to the considerable complexity and heterogeneity of the tectonic processes of the formation and evolution of the Pacific margin of Antarctica structures (Haeger et al., 2019).

The eastward movement of the asthenosphere flow in the region (from the Pacific Ocean to the back-arc basins of the South Sandwich island arc) creates additional powerful compression and expansion forces that contribute to the occurrence of intensive processes with the formation of young rift systems under the lithosphere regional stretching prevailing (Udintsev et al., 2010). The regional impact of this deep body influenced the distribution of density inhomogeneities of the earth's crust, which made it possible to restore the formation of the transition zone of the
Drake Passage and assess the possible age of the Bransfield Strait. Considering the age of the Bransfield Strait (26-37 million years), synchronous with the time of extensive sinking (to depths of 4.0-5.0 km) of the Drake Passage structures, as well as other extended areas of the Antarctic margin (Udintsev et al., 2010), it should be assumed that there is a common regional source of such transformations.

Following experimental results (Romashov, 2003), it can be assumed that a large mantle plume was formed in the region of abnormally elevated temperatures. It destroyed the outer shell of the lithosphere and was lifted to the surface, which led to the formation of extensive plateau-basalt fields between the South American and Antarctica continents (Udintsev et al., 2010). In the process of their cooling, radical processing of the upper layers of the Earth's crust and the formation of cracks filled with volcanic rocks took place, the age of which decreased with distance from the continent.

The age of linear magnetic anomalies can reflect the cooling time of melts lifted to the surface in the periodic processes of changing the thermal regime of vast sections of the upper mantle, as well as the action of powerful tectonic movements from the side of boundary structures.

Perhaps, this mechanism can explain the extended heterogeneity zones below the Moho section in deep VERS sections in the Drake Passage and the Scotia Sea. They may reflect the processes of primary crust processing as a result of the mantle melts lifting into the lithosphere of the region's structures. The process of a new crust formation, including a crust-mantle mixture in the upper crust, led to the separation of the South Shetland Islands from the Antarctic Peninsula. However, this process was not accompanied by the formation of an oceanic crust with a system of linear paleomagnetic anomalies.

\subsection{Frequency - resonance sounding results in the Bransfield Strait}

New data on the possible depth of the magma chambers of West Antarctica and Antarctica volcanic structures were obtained as a result of seasonal (2018) 
UAE work in the Antarctic region (Yakymchuk et al., 2019). Geophysical measurements were carried out with mobile direct-search technology, including flux metric surveying, deep VERS, as well as frequencyresonance processing and interpretation (decoding) of remote sensing data (satellite images) and photographs (Yakymchuk et al., 2019).

Bases (collections) of minerals and rocks in the modified versions of the vertical sounding and frequency resonance processing of satellite images methods were used. These works made it possible to obtain experimental (frequency-resonance) rock characteristics for separate local volcanoes and regional structures.

Deep soundings for the Bransfield Strait volcanic structures were carried out near the Elephant Island and Discovery Bay near Greenwich Island (Fig. 2).

Frequency-resonance characteristics from the samples' database were the reference to determine the structure of deep sections in the sounding points. The initial base of samples is systemic, opened for replenishment and inclusion of new elements.

The presence of sedimentary and igneous rocks was established by the deep-sea sounding results in Discovery Bay (Greenwich Island, South Shetland Islands) near Elephant Island.

Responses at various depths showed that sedimentary groups (clastic and clayey, volcano-clastic, and carbonate) can be traced to a depth of $3 \mathrm{~km}$. Below $(4-10 \mathrm{~km})$ responses from clastic rocks are traced, and responses from dolomites are recorded at depths of up to $60 \mathrm{~km}$. The melting layer is located at a depth of $202-227 \mathrm{~km}$, and the signal from igneous rocks (kimberlites) is traced at a depth of 140-723 km (except for the melting layer).

Sedimentary and carbonate rocks dominated in the section (up to $45 \mathrm{~km}$ ) according to the sounding results near the Elephant Island. Magma channel is highlighted here, and a signal is received from deep hydrocarbons and salt.

The obtained results with the known seismic models comparison showed that there are rocks with 5.8 $\mathrm{km} / \mathrm{s}$ velocity and a thickness of about $15 \mathrm{~km}$ at the Elephant Island crust. Deep dolomites identified by sounding near the island may have this velocity.
The structure of the Deception Island volcano was also studied with this technology. Carbonate and siliceous sedimentary rocks were identified in the volcanic structure (outside the central part section). Only carbonate rocks frequency responses were obtained in the center of this volcano. The roots of the deep fluids and minerals migration channel can be located in the zone of molten rocks at a depth of 195-225 km. Signals of oil, condensate, and gas (up to $57 \mathrm{~km}$ ) are identified in the deep frequency-resonance characteristic of the section of the Deception Island. The rocks with $\mathrm{V}=4.0-6.6 \mathrm{~km} / \mathrm{s}$ are located at a depth above $15-17 \mathrm{~km}$, which indirectly confirms the possible presence of carbonate rocks at great depths.

The total elemental composition of rocks of Deception Island data was obtained, where a wide range (over 85) of elements was revealed. Earlier, for the Deception Island rocks were obtained the quantitative characteristics of the elemental composition (for more than 30 elements) (Shnyukov et al., 2013).

Some submarine volcanoes of the Bransfield Strait were also studied by this technology using (Fig. 2). Signals for the Orca volcano were obtained for sedimentary (limestone, dolomite) rocks from an interval of 400-450 m to a depth of more than $200 \mathrm{~km}$. The existence of a melting layer at a depth of 220-222 km was revealed.

Responses for Bridgeman volcano (Fig. 2) were obtained for sedimentary rocks up to the melting layer at a depth of $225 \mathrm{~km}$. Responses from oil, condensate, and gas were obtained to a depth of $57 \mathrm{~km}$. In the deep section (up to the melting layer at a depth of $225 \mathrm{~km}$ ) of the Wordie volcano, carbonate and siliceous sedimentary formations were revealed.

The results of the remote determination of elemental (chemical) composition can be an important and additional argument in assessing the genesis of structures and their prospects for mineral accumulations.

\section{Conclusions}

The results of the northern volcanic branch of West Antarctica studies show the existence of a complex plume magma-gas-fluid system consisting of several shallow magma chambers (depth $\leq 10 \mathrm{~km}$ ). The mol- 
ten magmas rose directly from the mantle or the magma accumulation zone at a depth 25-30 km located. Our experimental data show that there is a molten zone at a $195-225 \mathrm{~km}$ where considerable part of volcanic roots is located. Certain structural patterns for land and submarine volcanic structures are revealed, and the first data on the deep migration channels of fluids in the Bransfield Strait are obtained. Volcanic channels are filled with different basic, ultramafic rocks and sedimentary rocks too. In some cases, it can be assumed that this melt zone can "breakthrough" with rocks of deeper migration channels of fluids, minerals, and rocks. The deep roots presence of volcanic structures can be associated with the pulsed functioning of a gas-fluid channel with a low viscosity. Due to this channel, gas-saturated melts rise and form some zones of intermediate crystallization. Certain structural patterns for inland and submarine volcanic structures are revealed, and the first data on the deep migration channels of fluids, minerals, and chemical elements in the Bransfield Strait are obtained.

The studies showed that multiphase pulsed volcanic activity mainly through the vertical migration channels of deep fluids and minerals from the melting zone, at the depth interval $195-225 \mathrm{~km}$ located played a significant role in the formation of tectonic diversity and the evolution of the structures at the Antarctic continental margins.

The volcanic structures with roots at various depths presence may be connected with the tectonic activation processes during the last 500 million years. The reference frequencies data for different types of rocks allow to study the deep Earths' structure and to solve many problems of minerals searching.

As a result of the practical application of the developed measuring equipment in various regions of the world, considerable evidence (facts) have been obtained in favor of the "volcanic" model of the formation of many structural elements of the Earth (and other planets and satellites of the Solar System).

The first results of the magmatic systems of the volcanic structures of the Bransfield Strait studying indicate the need for further research to understand the mechanisms of formation and evolution of structures and deep geospheres in different regions.
Author contributions. Conceptualization: VS and VB; methodology: NY and IK; software: NY; validation: VS and IK; investigation: NY and IK; writing - original draft preparation: VS, IK and VB. Each author contributed to the analysis and discussion of the results and edited the manuscript.

Acknowledgments. The authors express their deep gratitude to the State Institution National Antarctic Scientific Center, Ministry of Education and Science of Ukraine for the opportunity to carry out a significant amount of experimental geophysical research during the Ukrainian Maritime Antarctic Expedition on board the "Sea of Commonwealth" vessel in 2018 according to the State Special-Purpose Research Program in Antarctica for 2011-2020.

Funding. This research received no external funding.

Conflicts of Interest. The authors declare no conflict of interest.

\section{References}

Bakhmutov, V. G., Tretyak, K. R., Maksimchuk, V. Yu., Glotov, V. M., Grekhu, R. Kh., Egorova, T. P., Zalizovsky, A. V., Koloskov, O. V., Korchagin, I. M., \& Pronenko, V. O. (2017). Struktura i dynamika heofizychnykh poliv u Zakhidnii Antarktytsi [The structure and dynamics of geophysical fields at West Antarctica]. Lviv Polytechnik Publishing House. (in Ukrainian)

Berrocoso, M., Fernández-Ros, A., Prates, G., Garcia, A., \& Kraus, S. (2016). Geodetic implications on block formation and geodynamic domains in the South Shetland Islands, Antarctic Peninsula. Tectonophysics, 666, 211-219. https://doi. org/10.1016/j.tecto.2015.10.023

Catalan, M., Galindo-Zaldivar, J., Davila, J. M., Martos, Y. M., Maldonado, A., Gamboa, L., \& Schreider, A. A. (2013). Initial stages of oceanic spreading in the Bransfield Rift from magnetic and gravity data analysis. Tectonophysics, 585, 102112. https://doi.org/10.1016/j.tecto.2012.09.016

Dubinin, E. P., Kokhan, A. V., \& Suschevskaya, N. M. (2013). Tectonics and magmatism of ultraslow spreading ridges. Geotectonics, (47)3, 131-155. https://doi.org/10.7868/S0016853X1 3030028 (in Russian)

Fretzdorff S., Worthington T. J., Haase K. M., Hékinian, R., Franz, L., Keller, R. A., \& Stoffers, P. (2004). Magmatism in the Bransfield Basin: rifting of the South Shetland Arc. Journal of Geophysical Research: Solid Earth, 109, B12208, 1-19. https://doi.org/10.1029/2004JB003046

Geyer, A., Álvarez-Valero, A. M., Gisbert, G., Aulinas, M., Hernández-Barreña, D., Lobo, A., \& Marti, J. (2019). Deci- 
phering the evolution of Deception Island's magmatic system. Scientific Reports, 9, 373. https://doi.org/10.1038/s41598-01836188-4

Haeger, C., Kaban, M. K., Tesauro, M., Petrunin, A. G., \& Mooney, W. D. (2019). 3-D Density, Thermal, and Compositional Model of the Antarctic Lithosphere and Implications for Its Evolution. Geochemistry, Geophysics, Geosystems, 20(2), 688-707. https://doi.org/10.1029/2018GC008033

Janik, T., Grad, M., Guterch, A., \& Środa, P. (2014). The deep seismic structure of the Earth's crust along Antarctic Peninsula - A summary of the results from Polish geodynamical expeditions. Global and Planetary Change, 123B, 213-222. https://doi.org/10.1016/j.gloplacha.2014.08.018

Kozlenko Yu. V., \& Kozlenko, M. V. (2011). Application of density modeling for solving the problem on the nature of the Bransfield Strait. Geophysical Journal, 33(4), 142-152. (in Russian)

Kozlenko Yu., \& Kozlenko, M. (2019). Earth crust of the Bransfield Strait between Antarctic Peninsula and King George Island. Geology and Mineral Resources of World Ocean. 15(1), 63-73. https://doi.org/10.15407/gpimo2019.01.063 (in Russian)

Levashov, S. P., Yakymchuk, N. A., Korchagin, I. N., Bachmutov, V. G., Solovyov, V. D., \& Kozlenko, Yu. V. (2008). Geophysical models of Drake Passage and Bransfield Strait crustal structure. Ukrainian Antarctic Journal, 6-7, 9-14. https:// doi.org/10.33275/1727-7485.6-7.2008.486

Levashov, S. P., Yakymchuk, N. A., \& Korchagin, I. N. (2012). Frequency-resonance principle, mobile geoelectric technology: a new paradigm of geophysical investigations. Geophysical journal, 34(4), 167-176. (in Russian)

Lodolo, E., \& Perez, L. F. (2015). An abandoned rift in the southwestern part of the South Scotia Ridge (Antarctica): Implications for the genesis of the Bransfield Strait. Tectonics, 34(12), 2451- 2464. https://doi.org/10.1002/2015TC004041

Lösing, M., Ebbing, J., \& Szwillus, W. (2020). Geothermal Heat Flux in Antarctica: Assessing models and observations by Bayesian Inversion. Frontiers in Earth Science, 8, 105. https:// doi.org/10.3389/feart.2020.00105

Pedrera, A., Ruiz-Consta, A., Heredian, N., GalindoZaldívar, J., Bohoyo, F., Marín-Lechado, C., Ruano, P., \& Somoza, L. (2012). The fracture system and the melt emplacement beneath the Deception Island active volcano, South Shetland Islands, Antarctica. Antarctic Science, 24(2), 173182. https://doi.org/10.1017/S0954102011000794

Prudencio, J., Siena, L., Ibáñez, J. M., Pezzo, E., GarciaYeguas, A., \& Díaz-Moreno, A. (2015). The 3D Attenuation Structure of Deception Island (Antarctica). Surveys in Geophysics, 36(3), 371-390. https://doi.org/10.1007/s10712-0159322-6

Romashov, A. N. (2003). Planeta Zemlya. Tektonofizika $i$ evolyutsiya [Planet Earth: Tectonophysics and Evolution]. Editorial URSS. (in Russian)
Schreider, Al. A., Schreider, A. A., Galindo-Zaldivar, H., Maldonado, A., Gamboa, L., Martos, Y., Lobo, F., \& Evsenko, E. I. (2015). Structure of the Bransfield Strait crust. Oceanology, 55(1), 126-138. (in Russian)

Shnyukov, S. E., Lazareva, I. I., Khlon E. A., Mitrokhin, A. V., Morozenko, V. P., Marchenkov, D. F., Nikanorova, Yu. E., \& Osipenko, V. Yu. (2013). A model for forming volcanic and marine volcanogenic sedimentary rocks of the Deception Island (Western Antarctica): initial data for modeling. Geology and Mineral Resources of World Ocean, 1, 44-65. (in Russian)

Soloviev, V. D., Korchagin, I., Levashov S., Yakymchuk, N., \& Bozhezha, D. (2016). Central Basin of the Bransfield Strait: magnetic anomalies and the formation stages of the Antarctic Peninsula continental margin structures. Conference Proceedings, 15th EAGE International Conference on Geoinformatics Theoretical and Applied Aspects, 2016, 1-6. https://doi.org/10. 3997/2214-4609.201600452

Steig, E. J., Schneider, D. P., Rutherford, S. D., Mann, M. E., Comiso, J. C., \& Shindell, D. T. (2009). Warming of the Antarctic ice-sheet surface since the 1957 International Geophysical Year. Nature, 457, 459-462. https://doi.org/10.1038/ nature 07669

Teterin, D. E. (2011). Postmiocene geodynamic evolution of the Drake Passage, Western Antarctic Region, Southern Ocean. Izvestiya. Physics of the Solid Earth, 47(8), 653-668. (in Russian)

Udintsev, G. B., Beresnev, A. F., Kurentsova, N. A., Koltsova, A. V., Domoratskaya, L. G., Shenke, G. B., Ott, N., Kenig, M., Iokat, V., Bakhmutov, V. G., Solovyov, V. D., Levashov, S. P., Yakymchuk, N. A., \& Korchagin, I. N. (2010). Proliv Dreyka i more Skosha - okeanskiye vorota Zapadnoy Antarktiki [Drake Strait and the Skotia Sea - ocean gate of Western Antarctica]. In Yu. G. Leonov (Ed.), Structure and Evolution of the Lithosphere (pp. 66-90). Paulsen Editions. (in Russian)

Vries, M. V. W., Bingham, R. G., \& Hein, A. S. (2017). A new volcanic province: an inventory of subglacial volcanoes in West Antarctica. Geological Society, London, Special Publications, 461, 231-248. https://doi.org/10.1144/SP461.7

Xia, S., Zhao, F., Zhao, D., Fan, C., Wu, S., Mi, L., Sun, J., Cao, J., \& Wan, K. (2018). Crustal plumbing system of postrift magmatism in the northern margin of South China Sea: New insights from integrated seismology. Tectonophysics, 744, 227-238. https://doi.org/10.1016/j.tecto.2018.07.002

Yakymchuk, M. A. (2014). Electric field and its role in the life on Earth. Geoinformatika, 3, 10-20. (in Ukrainian)

Yakymchuk, N. A., \& Korchagin, I. N. (2019). Integral estimation of the deep structure of some volcanoes and cymberlite pipes of the Earth. Geoinformatika, 1(69), 28-38. (in Russian)

Yakymchuk, N. A., Korchagin, I. N., Bakhmutov, V. G., \& Solovjev, V. D. (2019). Geophysical investigation in the Ukrainian Marine Antarctic Expedition of 2018: mobile measur- 
ing equipment, innovative direct-prospecting methods, new results. Geoinformatika, 1(69), 5-27. (in Russian)

Zandomeneghi, D., Barclay, A., Almendros, J., Godoy, J. M. I., Wilcock, W. S. D., \& Ben-Zvi, T. (2009). Crustal structure of Deception Island volcano from $P$ wave seismic tomog- raphy: Tectonic and volcanic implications. Journal of Geophysical Research, 114, B06310. https://doi.org/10.1029/2008 JB006119

Received: 21 January 2021 Accepted: 17 June 2021

\section{В. Соловйов ${ }^{1, *}$, В. Бахмутов ${ }^{1,3}$, М. Якимчук ${ }^{2}$, I. Корчагін ${ }^{1}$}

${ }^{1}$ Інститут геофізики ім. С.І. Субботіна НАН України, м. Київ, 03680, Україна

2 ТОВ Інститут прикладних проблем екології, геофізики і геохімії, м. Київ, 01133, Україна

3 Державна установа Національний антарктичний науковий центр, МОН України, м. Київ, 01601, Україна

* Автор для кореспонденції: solvalera@ukr.net

\section{Глибинна структура і нові експериментальні дані про вулкани протоки Брансфілд (західна Антарктика)}

Реферат. Метою дослідження є виявлення та характеристика складної магмо-газофлюїдної системи для окремих структур північної вулканічної гілки західної Антарктики в протоці Брансфілд. Вона складається з декількох глибинних магматичних камер різного рівня з магмами, піднятими безпосередньо з мантії або із зони накопичення на границі земної кори та мантії (на глибині 25-30 км). Методи дослідження засновані на відомій ідеї, що Земля може бути розглянута як сферичний конденсатор, утворений різними шарами від свого ядра до поверхні з різними параметрами товщиною, діелектричною проникністю, щільністю, різницею контактних потенціалів. Матеріали глибинного частотнорезонансного зондування показують, що корені багатьох вулканів розташовані в шарі розплавлених порід на глибині 195-225 км і більше. Виявлено структурні закономірності вулканічних споруд та отримано перші дані про канали глибинної міграції флюїдів у протоці Брансфілд. За даними досліджень частотного резонансу, вертикальні канали вулканів заповнені базальтами, ультраосновними породами та різними групами осадових порід. Глибинні корені вулканічних структур можуть бути пов'язані з імпульсним функціонуванням газофлюїдного каналу з низькою в'язкістю. Завдяки цьому каналу насичені газом розплави утворюють в корі зони проміжної кристалізації. Результати модифікованих методів, що використовуються для обробки та декодування супутникових зображень та фотографій, дозволяють доповнити розуміння основних процесів формування структур західної Антарктики. Дослідження показали, що багатофазна імпульсна вулканічна активність, переважно через вертикальні канали міграції глибинних флюїдів із зони плавлення, розташованої в інтервалі глибин 195-225 км, відіграла значну роль у формуванні тектонічного різноманіття та еволюції структур континентальної окраїни Антарктичного регіону. Присутність вулканічних структур з корінням на різних глибинах свідчить про їх регулярний зв’язок із процесами тектонічної активації в цих регіонах, що відбувались за останні 500 мільйонів років. Використання еталонних частот для різних типів відомих порід дозволяє вивчити глибинну структуру нашої планети та вирішити проблеми пошуку корисних копалин. Результати вивчення магматичних систем протоки Брансфілд вказують на необхідність подальших досліджень механізмів утворення та еволюції структур і глибинних геосфер у різних регіонах Землі.

Ключові слова: глибинна будова, флюїди, підводні вулкани, мобільні технології, обробка даних, дистанційне зондування 